\title{
Researching sensitively without sensitising: Using a card sort in a concurrent mixed methods design to research trust and distrust
}

\begin{abstract}
Researchers exploring sensitive issues need to obtain valid and reliable information. This may necessitate participants not being sensitised to the precise research focus to prevent contamination of findings. In this paper research exploring feelings of trust and distrust and emotional responses to organisational change is used to assess how a concurrent mixed methods design, utilizing a constrained card sort and in-depth interview, can enable such sensitive issues to be researched without sensitising participants. This illustrative example provides instructive guidance regarding how to apply this mixed method. It also reveals how feelings of trust and distrust and emotional responses are directly associated with positively and negatively interpreted change situations rather than misappropriated, highlighting reasons for these responses including the role of managers. The paper concludes by considering how this mixed methods design can support researching such sensitive issues in organisations.
\end{abstract}

Keywords: sensitive issue, sensitise, card sort, mixed methods, trust, distrust, change 


\section{INTRODUCTION}

The primary purpose of this paper is to contribute to the organisational research methods literature in two ways: Firstly to answer the question, can a concurrent mixed methods design utilizing a card sort enable sensitive issues to be researched without sensitising participants? Secondly, with regard to the currently limited literature available about card sorts outside the field of expert systems, to illustrate and provide sufficient depth of instructive guidance to allow scholars to apply the method to their own research. We commence with an overview of the problem of obtaining valid and reliable information when asking questions about sensitive issues and the use of mixed methods. Within this we summarise the nature of sensitive issues and why it may be necessary to ensure participants are not sensitised to the precise research focus. We then consider the use of mixed methods research designs, and the potential of a concurrent design combining card sorts and in-depth interviews for researching sensitive topics without sensitising.

Following a consideration of sorting techniques, we offer a concurrent mixed methods design comprising a constrained card sort followed immediately by an in-depth interview as an illustrative example. This explores feelings of trust and distrust and emotional responses to positively and negatively interpreted organisational change situations to address two research questions: Firstly, are feelings of trust and distrust in positively and negatively interpreted change situations actually associated with reported emotional responses? And, secondly, what are the reasons for these feelings of trust and distrust?

Our discussion returns to our primary contribution. In this we consider how the concurrent mixed methods design can support the research of sensitive issues without sensitising participants.

\section{RESEARCHING SENSITIVELY AND MIXED METHODS RESEARCH DESIGNS}

The problem of obtaining useful information when asking questions about sensitive issues is widespread in research. Such issues comprise topics that participants are unwilling to discuss as they are felt embarrassing, threatening or incriminating, yet are often crucial to a fuller understanding (Jehn \& Jonsen, 2010). Notwithstanding problems associated with gaining access, or increased non-participation due to individuals expecting negative consequences, 
participants' evasive answers can reduce the interpretive power of data collected (Saunders, Lewis \& Thornhill, 2009). Invariably perceptions of what is sensitive are socially constructed: what matters is the extent each participant finds the research sensitive for whatever reason (Arksey \& Knight, 1999). In such situations, participants may use responses to protect themselves from potential harm or embarrassment, present themselves in a positive light, or please the researcher; potentially threatening accuracy or interpretation of data collected (Dalton, Daily \& Wimbush, 1997). Not surprisingly, this issue is recognized widely; most research methods texts emphasizing the need to minimize such problems by ensuring saliency of the topic and emphasising privacy and confidentiality (for example Kvale \& Brinkmann, 2009; Saunders et al., 2009).

Interviewing literature emphasises repeatedly the importance of building rapport with participants prior to asking questions about potentially sensitive issues (Arksey \& Knight, 1999; Dalton et al., 1997; Jehn \& Jonsen, 2010). Such texts expound how, when conducted by a skilled interviewer, face-to-face interviews can elicit honest responses regarding participants' feelings about sensitive topics, revealing insightful information whilst minimizing the likelihood of upset or distress. Whilst advice on how to ask questions on sensitive topics such as trust and distrust varies enormously between texts, that in Lee's (1993) seminal text Doing Research on Sensitive Topics is extensive. Drawing upon Lee's (1993) work, it is clear that, even when usual assurances of confidentiality are given, posing an intrusive question on a topic perceived as sensitive is likely to give poor results (Van Der Heijden, Van Gils, Bouts \& Hox, 2000). It is therefore crucial that during data collection researchers allow participants' cooperation and trust to be gained, so responses are candid and made without fear of compromise (Dalton et al., 1997, Jehn \& Jonsen, 2010), where necessary combining different data methods to increase understanding (Saunders et al. 2009).

Where precise research foci are explained in detail at the outset of an interview, this is likely to raise their importance in each participant's consciousness; perhaps introducing bias and compromising or limiting scope to develop new understandings. It may therefore be necessary to avoid sensitising participants to the focus of the research (Lee, 1993) and adopt data collection methods which minimise participants' reactivity, allowing them to respond naturally (Miles, 1979). 
Using mixed methods research has been argued to provide additional complimentary data and increase interpretive power (Edmondson \& McManus, 2007). Where research questions require rich detailed data, as is often the case in understanding sensitive topics, qualitative methods are usually prioritised or emphasised, quantitative methods being complementary. In contrast, where research questions require statistical representation, quantitative methods are likely to be prioritised (Teddlie \& Tashakkori, 2010). Despite this, an analysis of three business and management journals (Molina-Azorin, 2011) indicates over two thirds of studies prioritise quantitative methods, these being used sequentially after qualitative methods.

In concurrent mixed methods designs, data are collected and analyzed in parallel (Creswell, Plano-Clark \& Garrett, 2008) rather than sequentially, allowing findings from one data collection method to inform the other immediately. This supports enhancement and clarification through the identification of additional insights to explain more fully the phenomenon being researched (Hammersley, 2008). For topics where the researcher does not wish to sensitise the participant to the precise focus of the research, findings based on quantitative data collected about a set of items may offer a way of establishing immediately the relative importance of a subset that is of particular interest, prior to exploring underlying reasons in an in-depth interview.

Drawing upon concurrent designs, sensitive application of a sorting technique and an indepth interview could offer a means of integrating quantitative data about strength of feeling with a qualitative data exploring reasons for this. Through sorting the relative strength (if any) of feelings of trust and distrust along with a range of different emotions, perceptions could be established without sensitising respondents to the researcher's precise focus. At the same time this could assist the building of rapport prior to an in-depth interview which explores a potentially sensitive topic and the reasons for these feelings and other emotions. It is to the design and use of such sorting techniques that we now turn.

\section{AN OVERVIEW OF SORTING TECHNIQUES}

Sorting techniques involve participants sorting items or stimuli such as physical objects, pictures or cards containing words into different groups, thereby allowing their item categorizations to be elicited (Whaley \& Longoria, 2009). As a means of elicitation, such 
techniques have a number of advantages. In particular, simplicity of administration, ease of understanding for the participant and process speed (Fincher \& Tenenberg, 2005).

Combining a sort with an in-depth interview in a mixed methods design offers an opportunity to explore and understand participants' reasons for their categorizations, helping make sense of the data collected.

Sorting techniques have their origin in Kelly's (1955) Personal Construct Theory. This is based on the belief that, although people categorize items differently, there is sufficient commonality to enable understandings alongside sufficient differences to support individuality (Butt, 2008). Participants' feelings are reflected by their placing items into categories on the basis of their own reasons. An employee may classify an item such as 'trusting' into one of a number of categories reflecting the extent she or he feels it, based on reasons relating to how a process has been managed by their employing organisation.

A card sort offers a simple form of sorting technique, each item usually consisting of a card with a word or phrase printed on it. Participants sort these cards into either categories supplied by the researcher or categories they develop themselves, the former being referred to as a constrained card sort (Rugg \& McGeorge, 2005). Use of researcher supplied categories enables comparison of responses, providing categories provided are both realistic and understood by participants. It is this form of card sort which is the focus of this paper.

Limited advice exists on the use of card sorts within the research methods literature, a notable exception being Rugg and McGeorge (2005) in relation to expert systems. Their 'tutorial' article begins to address this deficit highlighting how, compared to other techniques such as repertory grids, sorting has received little formal attention. Commencing with advice regarding content and number of cards, they suggest content can be derived through either preliminary research or from the literature, stressing it should be from within the same horizontal level in a hierarchy; for example individual employees' emotional responses to organisational change. Rugg and McGeorge (2005) state there should be no fewer than eight cards and a maximum of between 20 and 30 cards for single criterion repeated sorts.

However, they observe a greater number of cards may be sorted in some circumstances, as we illustrate later. 
Once content has been chosen, cards need to be prepared for physical sorting. Rugg and McGeorge (2005) advise: When preparing cards, all should be the same size, words or phrases on every card being printed using the same font and font size. Where a constrained sort is used, they advise clear labels are provided for each sort category. Finally they emphasise that instructions to participants regarding sorting criteria should be clear, the process being explained precisely by the researcher.

Results record the details of the sort, the categories used and the cards placed into each category. These data are subsequently analyzed, often quantitatively and on their own. However, as noted earlier it can be advantageous to use a card sort as part of a mixed methods design, a concurrent in-depth interview allowing exploration of reasoning for categorizations (Saunders and Thornhill, 2004).

\section{RESEARCHING SENSITIVE ISSUES WITHOUT SENSITISING: TRUST, DISTRUST AND EMOTIONAL RESPONSES TO ORGANISATIONAL CHANGE}

\section{An Overview of the Literature}

Over the past decade agreement has emerged regarding the definition of trust: "a psychological state comprising the intention to accept vulnerability based upon positive expectations of the intentions or behaviours of another" (Rousseau, Sitkin, Burt \& Kramer 1998: 395). Outlined in similar terms by scholars such as Mayer, Davis, and Schoorman (1995) trust is seen to bring together the notion of favourable expectations regarding the intentions and behaviour of another party and a willingness to become vulnerable to that party (McEvily \& Tortoriello, 2011).

Distrust is defined in opposite terms using notions of unfavourable expectations and unwillingness to become vulnerable (Kramer, 1999). However, there is disagreement as to whether trust and distrust are simply opposite ends of a single trust-distrust construct, the occurrence of one precluding the other (Bigley \& Pearce, 1998; Schoorman, Mayer \& Davis, 2007) or separate but linked constructs (Lewicki, McAllister \& Bies, 1998; McKnight \& Chervany, 2001; Sitkin \& Roth, 1993). Drawing on empirical work, both views have been 
integrated into a trust-distrust ${ }^{1}$-absence triangle incorporating trust and distrust as separate dimensions and opposite ends of a continuum (Saunders \& Thornhill, 2004). This model emphasises that, for specific situations, trustors may be trusting with an absence of distrust, distrustful with an absence of trust, neither trusting nor distrustful or, occasionally, both trusting and distrustful.

Within organisations managers undertake activities because of the power and authority in their roles, rather than their personal views (Luhmann, 1979). The ways in which activities are undertaken, particularly with regard to discretionary behaviours (Bijlsma \& Van de Bunt, 2003), will affect employees' expectations of favourable (or unfavourable) treatment and, consequently, their trust (and distrust) judgements. Initially such judgements will be based upon rational choice, expectations about perceived intentions being derived from credible information from others rather than personal experience. Repeated positive interactions will, over time, build upon this calculus based trust to engender high levels of relational trust (Schminke, Cropanzano \& Rupp, 2002; Willemyns, Gallois \& Callan, 2003). Where positive emotions are directed towards specific people, institutions or groups and causally dependent upon expectations about them, they have been argued to be part of trust risk assessments (Becker, 1996). Within this, the importance of relationships between employees (trustors) and managers (trustees) has been emphasised (Saunders \& Thornhill, 2003, 2004; Young and Daniel, 2003). Saunders and Thornhill (2003, 2004) found negative interactions and associated emotional responses were associated with distrust. Such negative emotions influenced assessment of risk negatively, and thus distrust (Young \& Daniel, 2003).

More recent research has questioned this link between trust and emotion arguing it may be incidental, trustors misattributing emotions to trust from situations where their appraisal is consistent with, but not causally related to, the task being evaluated (Dunn \& Schweitzer, 2005). For example, a trusting employee who feels hopeful may associate their hope with becoming a parent rather than the repeated positive interactions during organisational change and their trust judgement. This raises two research questions in relation to trust: Firstly are trust and distrust judgements in positively and negatively interpreted change situations actually associated with reported emotional responses? And, secondly, what are the reasons

\footnotetext{
${ }^{1}$ Saunders \& Thornhill (2004) use the term 'mistrust', arguing that mistrust and distrust are treated synonymously as the opposite of trust.
} 
for these judgements? Investigating how individuals feel about organisational change also presents a research situation in which data need to be collected on a potentially sensitive topic about which people are likely to have developed strong feelings, whilst not sensitising participants to the precise focus.

\section{Method: using a card sort and in-depth interview concurrently}

Within trust research, constrained card sorts have been used to establish participants' trust/distrust judgements and emotional expressions and integrated with simultaneous audio recorded in-depth interviews to explore and explain the reasons for each participant's categorization and interpretation of their associated context. To date the approach has been used to research the strength of trust relative to other feelings in different change contexts (Saunders \& Thornhill, 2003; Saunders, 2011) and whether trust and distrust are symmetrical with the occurrence of one precluding the other (Saunders \& Thornhill, 2004). Similar mixed methods designs (with variations in cards sorted) have been used to explore external organisational change situations, for example downsizing (Saunders, Thornhill \& Stead, 1997) and mergers and acquisitions (Saunders, Altinay \& Riordan, 2009).

Using the research design outlined above, data were collected regarding employees' reactions to change in two case study public sector organisations referred to as 'Shirecounty' and 'Shiredistrict'. Both had come into existence on $1^{\text {st }}$ April 1998, as part of the local government reorganisation in England and Wales, Shirecounty having approximately 4400 employees (excluding School based staff) and Shiredistrict 600 employees. Shirecounty is responsible for the provision of education, caring services, police, traffic, road building and maintenance, libraries and strategic planning in a largely rural county. Shiredistrict provides different services, being responsible for development planning, leisure, refuse collection and street cleaning to part of a different rural county. Change involving restructuring was being undertaken in both organisations in response to UK government agendas reflecting continuous improvement expectations for local government.

The UK Government's Audit Commission (2007, 2009a) had recognised Shirecounty's performance, since 2005 awarding their highest rating 'performing strongly'. This was 
reflected in their 2008 Assessment Report ${ }^{2}$ which praised the 'outstanding cultural change'; throughout which there had been no compulsory redundancies. Formal communication channels including a weekly newsletter and regular team briefings were used to keep employees informed. While the need for new organisational structures had created uncertainty, Shirecounty's Chief Officers' Management Board perceived little employee resistance to the change.

In contrast, Shiredistrict's Directors' and Heads of Services' Group perceived considerable employee resistance. Change at Shiredistrict had involved restructuring and compulsory redundancies. Formal communication was acknowledged to have been limited and selective prior to the appointment of a new Chief Executive in the year preceding this research.

Although Shiredistrict had been rated by the Audit Commission (2009b) as 'performing well' since 2005, the associated Audit Report ${ }^{2}$ highlighted improvement was 'below average' and employees' sickness levels were 'high'.

This research was conducted in accordance with University ethical protocols. Formal permission was obtained to undertake the research from both organisations. Two random samples were then selected of 34 employees (Shirecounty) and 30 employees (Shiredistrict) stratified across each organisation's directorates according to level within the hierarchy. These comprised six senior managers, three from each organisation, 34 middle manager or professional employees ( 18 Shirecounty, 16 Shiredistrict) and 24 junior administrative, clerical or technical employees (13 Shirecounty, 11 Shiredistrict). All employees selected agreed to take part and, although not used, counselling support was available had the process caused stress.

The constrained card sort and concurrent in-depth interview were conducted in private in a familiar neutral place in each employee's work place, thereby helping place participants at ease (Jehn \& Jonsen, 2010). Prior to commencing the overall purpose: "to establish and understand employees' feelings about the managed change at Shirecounty/Shiredistrict" was stated. It was emphasised that there were no wrong answers. By not explicitly referring to trust, distrust or emotions, participants were not sensitised to these terms or the precise focus

\footnotetext{
${ }^{2}$ Full references to Shirecounty's Corporate Assessment Report are Shiredistrict's Annual Audit Report are not included to preserve anonymity. Reports for all English Local Authorities are available at http://www.auditcommission.gov.uk/audit/Pages/Default.aspx
} 
of the research. Assurances of anonymity were provided and it was emphasised that participation was not obligatory and, even if participants chose to take part and signed the consent form, they could withdraw at any time. This was repeated on the information sheet given at the same time. There was no discussion of the organisation or associated changes before the card sort commenced, no further detail being given regarding the focus of the research.

The card sort involved each participant sorting 50 randomly presented cards, each stating one 'feeling' that he or she might be experiencing in relation to the change. 'Feelings' were derived from the academic literature and expressed in the active voice; for example 'angry' rather than "anger". They included 'trusting' and 'distrustful', 13 expressions and manifestations of trust and distrust identified by Lewicki et al. (1998) ${ }^{3}$ and 35 emotions identified and used by Saunders \& Thornhill (2004) ${ }^{4}$, derived originally from literatures relating to psychology and stress.

For the first sort each participant was given the complete set of cards and asked to sort them for the displayed statement "Your feelings about the managed change at Shirecounty/Shiredistrict", using displayed headings "do not feel" or "feel to some extent" (Figure 1). During sorting, participants were allowed to move cards between these headings. When the meaning of a card was questioned or advice sought regarding the change focus, it was explained their views and understandings were what was important. Following completion of this first sort, cards containing a 'feeling' categorised as "do not feel" were removed and recorded. Each participant was then asked to undertake two further sorts of the remaining cards. In the second, the remaining cards were categorized using the displayed headings "feel to some extent" and "feel strongly". Those cards that were categorized as "feel to some extent" were removed and recorded. In the third sort each participant identified three cards from those they had placed under the heading "feel strongly" to place under the heading "feel most strongly". The cards categorised as "feel strongly" were removed and recorded. Although cards were presented at random, their order on the recording sheet

\footnotetext{
${ }^{3}$ The six expressions were: confident, cynical, faithful, fearful, hopeful and sceptical. The seven manifestations were: assured, hesitant, low monitoring, passive, take the initiative, vigilant and wary and watchful.

${ }^{4}$ The 35 emotions were: angry, calm, cheerful, comfortable, concerned, confused, demoralised, depressed, determined, disinterested, eager, enthusiastic, excited, expectant, frustrated, in control, indifferent, insecure, involved, keen, on edge, optimistic, overwhelmed, panicky, positive, powerless, relaxed, relieved, resentful, resigned, secure, stressed, under pressure, vulnerable, worried.
} 
(Figure 2) grouped feelings earlier research indicated were likely to be related in close proximity.

\section{[Insert Figure 1 and Figure 2]}

Sorting provided quantitative data on each 'feeling' using a four point ordinal scale. These ordinal data allowed the number of participants selecting each emotion, expression or manifestation, the relative strength of feeling and their relationship with feelings of trust and distrust to be established. The recording sheet allowed patterns identified by the card sort to be seen more easily, aiding subsequent in-depth interviews in which the reasons for selection of 'feelings' were probed.

Each interview flowed seamlessly from the constrained card sort, commencing with a discussion of the participant's reasons for categorizing the three 'feeling's felt most strongly (Figure 1). During this confidentiality was stressed repeatedly, it being demonstrated by not providing information about other participants' responses, even when asked. When not among those felt most strongly, the selection and relative positions of 'trusting' and 'distrustful', were introduced using the question “...I've notice that you categorized... can we talk about this?" This allowed the structure for each interview to be grounded in the participant's categorization of their 'feelings' in relation to the organisational change, involving a form of participant validation during the interview (Pidgeon, 1996). Participants were encouraged to discuss and explain their feelings in the context of their own interpretations and experiences of the change, allowing them to be explored from a grounded and subjective perspective. Because relative rankings of each participant's 'feelings' were introduced in a manner related precisely to their own categorization, reasons for the selection and relative strength of seemingly contradictory feelings could be explored. The entire process took approximately one hour.

The card sort and in-depth interview data were used initially to make sense of participants' trust and distrust judgements in the context of their interpretations of managed change in their organisations. Following Saunders and Thornhill (2004), participants' rankings of 'trusting' and 'distrustful' were used to categorise them as: trusting ('feel to some extent', 'feel strongly', 'feel most strongly') with absence of distrust ('do not feel'), distrustful ('feel to some extent', 'feel strongly', 'feel most strongly') with absence of trust ('do not feel'), neither trusting nor distrustful or both trusting and distrustful. Using agreed definitions, we 
then coded independently each paragraph of interview data according to whether that participant appeared to interpret the change in their organisation as positive, negative, mixed (both positive and negative), or unclear. Where we disagreed, we discussed differences and clarified our definitions. Using this process each participant's overall interpretation of the change was placed in one of three groups: Focussing on negative aspects, focussing on positive aspects, or having mixed feelings. This was combined subsequently with card sort data and analysis of interview responses, to enable feelings of trust and distrust in relation to the managed change to be contextualised within participants' interpretations of the change, the associated emotions felt and reasons for these. Through this process we developed our analysis in a way that was grounded in the participants' data and could be recognised as valid by them.

\section{Findings}

Initial categorisation of all participants according to whether they felt' trusting' with absence of distrust, 'distrustful' with absence of trust, or neither trusting nor distrustful revealed a significant association with their overall interpretation of the change, $\chi^{2}(4, N=63)=34.25$, $p<.001$, (Table 1). For the 30 trusting participants, nearly three quarters (73.3\%) interpreted the change as positive, only one interpreting it as negative; the majority being Shirecounty employees. In contrast, $80 \%$ of the 22 distrustful participants interpreted the change as negative, only one interpreting it as positive; the majority being Shiredistrict employees. Overall interpretations of the change for remaining participants who were neither trusting nor distrustful were more varied, although over half (54.5\%) still focussed on positive aspects. Proportions of trusting (23.3\%), distrustful (22.7\%) and neither trusting nor distrustful (27.3\%) participants who had mixed feelings about the change were similar.

[Insert Table 1 about here]

To explore whether trust and distrust judgements in positively and negatively interpreted change situations were associated with reported emotional responses and reasons for this, analysis was undertaken combining card sort and interview data. Each participant's trust judgement was considered with regard to their overall interpretation of the change as positive, negative or neutral; their three most strongly felt emotions, and explanations offered regarding the selection of these emotions. 


\section{Trusting with absence of distrust}

Of the 23 Shirecounty trusting participants, 16 focussed on positive aspects in their overall interpretation of the change, the majority discussing this in relation to the organisation and their own work. Those 'feelings' selected as the three felt most strongly included the emotions 'positive', involved', 'determined' and 'enthusiastic' (Table 2). Typically one programme manager articulated his choice of selecting 'involved' in relation to the change: “...I feel very involved on a lot of different levels. I have done lots of interesting things..... I have been involved in very small stuff to exciting stuff. People have taken a chance on me and it's great. I started in [date]. I am also involved at a political level with members. I love working with members and the democratic bit. Now I am moving sideways from customer services side". Another, a senior manager justified selecting the emotion 'confident' as one of those he felt most strongly in relation to the change: "I have a lot of confidence in the C.E.O. There is an air of enthusiasm and confidence and a desire to improve in the authority" again illustrating how emotions were directed to people (Becker, 1996).

[Insert Table 2 about here]

In contrast, far fewer (6) Shiredistrict trusting participants focussed on positive aspects in their overall interpretation of the change. While virtually all those 'feelings' selected as felt most strongly had also been selected by Shirecounty respondents, the emotion 'optimistic' was given more prominence (Table 2) reflecting the Shiredistrict context. Those in senior management positions focussed on the need for change and the general benefits of the process undertaken and their confidence in the new management team. This was typified by one recently appointed senior manager who stated Shiredistrict now had: “...a process that is being properly managed and that [it] delivers what is intended in the first place. The officer level has been reassured in the new management team. The Chief Executive and Senior Management Team in place gives biggest grounds for my optimism." Similar reasons were also offered by more junior employees, one's explanation for 'trusting' indicating how his faith in the new management team and associated optimism appeared causally dependent (Becker, 1996) on expectations: "They're good managers, so from that point of view the Chief Executive is very experienced and was brought in to restructure council. She's done it previously, so I feel we're being led by someone who knows what the score is. I trust her. This cascades down so that I trust my managers to the benefit of the council..." Although 
trusting Shiredistrict participants explained their selection of emotions such as 'positive' and 'optimistic' in terms of the new management team's abilities, they recognised how their involvement by line managers and open communication had been important in creating trust. In making these and other observations, trusting Shiredistrict participants considered there was no reason to be fearful regarding what was happening and, consequently no reason to feel 'distrustful'.

The remaining six trusting Shirecounty (and one Shiredistrict) participants focussed on both positive and negative aspects in their overall interpretation of the change when explaining most strongly felt emotions. Although these participants explained choices such as 'determined' and 'cheerful' in terms of their organisational roles, their work team and their job security; those from Shirecounty in more junior positions were 'frustrated' by the change, there being "no clear route to progress" (Table 2). While these participants did not expect harmful actions, they were 'sceptical' or 'concerned' regarding official information and, consequently, were often only 'trusting' to some extent. A junior Shirecounty administrator summarised this: "there is a natural sense of not quite believing what the Council tells you something that everyone probably thinks". Another, whilst still 'trusting', tempered his expectation of favourable treatment by his manager arguing "Managers may not be able to do anything about the situation because we are in a less valued area (job role), compared to another.... At a higher organisational level, I cannot relate to trusting." While he was not 'distrustful', not expecting to be treated unfavourably, this participant accepted what was occurring and was neither 'cynical' nor 'sceptical'. This suggests their overall interpretations of the change were also influencing the focus of their trust, as well as being related to those emotions most strongly felt.

\section{Distrustful with an absence of trust}

Only five (15\%) Shirecounty participants were distrustful with an absence of trust, contrasting markedly with Shiredistrict's 17 (57\%) participants in this category. $12(71 \%)$ of Shiredistrict's distrustful participants' overall interpretation of the change focussed on negative aspects, their strongest emotions including 'concerned', 'resigned', 'confused' and 'frustrated' (Table 2). For these employees, their negative interpretation and feeling of distrust related to harm had not been misappropriated. Rather, they believed the change had caused and would cause harm directly to themselves and their colleagues. While 'resigned' to the need for change at Shiredistrict, distrustful participants were 'concerned' about the 
future. This was typified by a male administrator who, although “...concerned about job security...", also recognised "...one of the reasons behind the changes is that the organisation seemed top-heavy. The people who have gone have been higher-level managers. That could be a good thing done. But does that band [of managers] being removed put more pressure on those left behind?" Like other employees, while he was 'distrustful' because of his own likely redundancy, there was an absence of any expectation of beneficial actions and consequently he was not trusting.

Distrustful Shiredistrict participants in middle management, professional and more junior roles emphasised a perceived lack of consultation during the change. A male professional employee who had selected 'powerless', 'resigned' and 'vulnerable' as his three strongest emotions summarised his own reasons for distrust as well as those of others: "Management have an idea of what they want and who they want and will stop at nothing to achieve targets. I am resigned to fact there is nothing you can do, you are just a number in a hat and you will be drawn if you are lucky. I feel that management's minds have been made up before process started, I don't think consultation information has been taken on board, they just do what they want..." While this emphasises clearly both powerlessness and attributing premeditated intentions to disregard the consultation's findings, it highlights his feeling of resignation and a passive acceptance of what has happened. It also indicates distrust and other emotions were felt in relation to the change (Becker, 1996) rather than being misappropriated (Dunn \& Schweitzer, 2005).

The five distrustful Shiredistrict participants whose overall interpretations of the change focussed on both positive and negative aspects were 'concerned' that the changes being implemented would not improve the services offered for Shiredistrict's customers (Table 2). Like other distrustful participants, they emphasised concerns regarding future unfavourable treatment to themselves and the existence of a "hidden agenda to reduce staff", one referring to recently appointed middle managers as "hatchet men". Another, a technician, talked about his likelihood of being made redundant: “...purely because the way I have seen the structure come through from Head of Service it looked like my post maybe the one that may become redundant. The Head of Service said that he didn't want drawings (my role) done in-house wanted function outsourced... out of my section I feel bottom of them in terms of qualifications and I am also the newest member so feel most vulnerable... I see my self as most vulnerable." While these participants recognised the need for Shiredistrict's change, 
they commented that management behaviour and in particular poor communication and withholding of information by senior management had resulted in distrust and a "them and us" attitude. Two participants, despite highlighting harm to themselves caused by the change, were 'determined'. One, an administrative manager, commented "Do I want the challenge? I said I did. I knew it would be stormy to begin with and I haven't been proved wrong. I went in with my eyes open. I don't think with the managing change process people were aware of the impact. A lot of people were quite sceptical that it will work."

The four distrustful Shirecounty participants, whose overall interpretation focused upon negative outcomes of change selected emotions such as 'stressed', 'resentful' and 'frustrated'. When talking about their most strongly felt emotions they highlighted differences in their own and immediate colleagues', often discretionary, treatment by management believing it to be harmful (Table 2). One administrator, talking about feeling 'resentful' commented: "I had to go to the Director over payment for flexi-time yet they were willing to pay other people. Other managers had treated me badly. I was "bollocked" over a pathetic issue" emphasising the impact of negative treatment in distrust judgements (Bijlsma \& Van de Blunt, 2003). However, as in Shiredistrict, discussion of their distrust focussed primarily upon the actions and attitudes of senior management rather than line managers.

\section{Neither trusting nor distrustful}

Feelings of both trust and distrust were absent for 11 participants from the two organisations. For the majority of these participants overall interpretation focussed on either positive aspects or both positive and negative aspects of the change. The six who were positive about change were determined to succeed both for themselves and for the sections within the directorates for which they worked. In all cases these participants appeared 'secure' about their future employment within their organisations, although they did not feel this most strongly. These participants did not feel 'trusting' and were not expecting the future to benefit either them or the sector in which they worked. "I don't feel trusting simply because of the way the Local Government is going is to set itself up more as a market place..." Similarly, participants did not feel 'distrustful' as there was an absence of intended harm, one explaining this: "I don't feel in relation to my work that anyone is trying to do anything behind my back."

The three participants who focussed on both positive and negative aspects of the change appeared less certain regarding their relationships with their immediate line managers and did 
not wish to be involved. One 'cheerful' and 'sceptical' clerical worker typified this commenting: "I'm cynical -it's here we go again. This is why I distance myself from the Council. In a humorous way it doesn't get me down. But then I'm not important, I'm not going to affect anything as I'm not management." This employee had neither expectation of beneficial actions nor of intended harm, similar feelings being apparent in both more junior and middle managers. The two participants who interpreted the change negatively, attributed this to stress, frustration and insecurity regarding their future within their organisation rather than any expectation of intended harm.

\section{Summary: Trust and distrust, emotional responses and the role of managers}

Participants trust and distrust judgements were significantly associated with their interpretations of their organisational change situations. Where they interpreted the change situation positively, participants were more likely to feel trusting in relation to the change, their emotional responses also being positive. Conversely, where the change situation was interpreted negatively they were more likely to feel distrustful, their emotional responses also being negative. In response to our first research question, interviews suggested these emotional responses were, like their feelings of trust and distrust, causally dependent on their experiences and expectations of the change situation (Becker 1996), rather than being misattributed from another situation (Dunn \& Schweitzer, 2005). Reasons for emotions and trust/distrust judgements (our second trust research question) included frequent reference to line managers' conduct and discretionary behaviours and their abilities. This lends support to earlier research emphasising the importance of managers in trust/distrust judgements (Saunders \& Thornhill, 2004; Young \& Daniel, 2003) and the role of discretionary behaviours (Bijlsma \& Van de Blunt, 2003).

\section{RESEARCHING SENSITIVELY WITHOUT SENSITISING -THE CONTRIBUTION OF CONCURRENT MIXED METHODS}

\section{Sensitive issues and sensitising}

Consideration of the data collected through the constrained card sort and concurrent in-depth interview shows how this mixed methods design can enable collection of data about sensitive issues while not sensitising participants to the precise focus of the research. Examination of 
Table 1 provided initial insights regarding whether the card sort sensitised participants to the precise focus of the research in both Shirecounty and Shiredistrict. If participants had been sensitised to the precise research focus, it would have seemed probable that both trust and distrust would have featured more frequently. This was not the case for participants from either organisation. 11 participants felt neither trusting nor distrustful, only one feeling both 'trusting' and 'distrustful' to some extent.

In their subsequent explanations for selecting 'trusting' participants' reasons differed, highlighting the importance of interviews to help understand the reasons behind their categorizations. For example, explanations from the Shirecounty participants who felt 'trusting' emphasised they were 'positive, 'involved' and 'confident' in management, these emotions all being related directly to the change situation rather than being misappropriated. In contrast, explanations from the Shiredistrict employees who felt 'trusting' focussed on their being 'confident' in the new management and 'optimistic' for the future, these like 'trusting' being directly related to the changes.

A review of audio recordings and interview notes offered insights regarding how the sorting process supported the building of rapport between the interviewer and participant.

Participants became noticeably more relaxed as their sorting progressed, appearing to enjoy the activity, one even requesting a copy to use in his own work. Their active engagement in this process appeared to help enable the discussion of sensitive topics in subsequent in-depth interviews. Although responses in interviews are invariably in part a product of the interviewer's skills, the extracts from participants' explanations for their categorizations highlighted how they were willing to answer questions that might be considered intrusive regarding sensitive issues. Throughout the 64 interviews, only one participant declined to discuss an issue further due to its sensitivity. While this might be argued to be because other participants did not consider the topic sensitive, their comments suggest otherwise. This was particularly apparent in Shiredistrict where over two thirds of participants felt 'distrustful'. These participants were willing to talk openly about personal issues such as their own vulnerability and the likelihood of being made redundant.

\section{The contribution of a concurrent mixed methods design}


This paper has outlined and illustrated the contribution an infrequently used concurrent quantitative and qualitative mixed methods design (Molina-Azorin, 2011) can make to introducing questions about sensitive issues that might be considered intrusive, in a nonthreatening manner. Initial use of a quantitative constrained card sort can offer an additional opportunity to build rapport with each participant, through an exercise which draws directly on the experience of each participant. Concurrent in-depth qualitative interviews allow participants' categorizations of feelings to be considered and understood in the contexts from which they were derived. By focussing initially upon feelings ranked through the card sort, participants are unlikely to be sensitised to the precise research focus and their reactivity minimized.

Concurrent collection creates an opportunity to use card sort data to directly and immediately inform the in-depth interview, yielding deeper richer understandings (Molina-Azorin, 2009) such as how feelings of trust and distrust are related to conduct of line managers. This is important as, in addition to allowing reasons for feelings in relation to sensitive issues to be established, these feelings can be considered in relation to the context in which they occur. Combining data from a card sort with data from in-depth interviews appears particularly beneficial to study phenomena such as trust and distrust, which are likely to be affected by equivocality amongst participants. The use of an in-depth interview alongside a card sort enables the researcher to ensure she or he has the same understanding of the words or phrases on the cards as the participant (Kvale \& Brinkmann, 2009) and that emotions, supposedly felt in relation to trust and distrust have not been misappropriated. Not sensitising these participants to a precise focus, allows what might be considered unusual selection of feelings (Lee, 1993) such as both 'cheerful' and 'sceptical', to surface. These can be explored immediately in the in-depth interviews, again without sensitising participants to the precise focus.

Invariably, and in accordance with our pragmatist philosophy, the adoption of concurrent mixed methods is dependent upon its suitability to answer the research question. Hence, as researchers, we first have to justify why their particular research question profits from this design. In addition we need to demonstrate how the data can be integrated usefully (Feilzer, 2010) providing fuller understandings and additional insights. Both aspects are important as the use of a card sort and in-depth interview as outlined requires considerable preparation as well as the time for data collection. This we contend is worthwhile. The adoption of mixed 
methods can support a better understanding (Greene, 2007) of issues such as trust and distrust that are, to many, sensitive.

\section{REFERENCES}

Arksey, H. \& Knight, P. (1999). Interviewing for Social Scientists. London: Sage.

Audit Commission. (2007). CPA -The Harder Test: Scores and analysis of performance in single tier and county councils 2006 London: Audit Commission [Accessed 1 February 2011] Available at: http://www.auditcommission.gov.uk/SiteCollectionDocuments/InspectionOutput/CPATheHarderTest2006.pdf

Audit Commission. (2009a). CPA -The Harder Test: Scores and analysis of performance in single tier and county councils 2008 London: Audit Commission [Accessed 1 February 2011] Available at: http://www.auditcommission.gov.uk/SiteCollectionDocuments/AnnualReports/2009/05032009CPATheHarder TestREP.pdf

Audit Commission. (2009b). CPA for District Councils: Spreadsheet of CPA Scores. Available at http://www.auditcommission.gov.uk/localgov/audit/cpa/CPA_district/Pages/spreadsheetofcpascores.aspx [Accessed 1 February 2011].

Becker, L.C. (1996). Trust as noncognitive security about motives. Ethics. 107: 43-61.

Bigley, G.A. \& Pearce, J.L. (1998). 'Straining for Shared Meaning in Organizational Science: Problems of Trust and Distrust', Academy of Management Review 23: 405-21.

Bijlsma, K.M. \& Van de Bubt, G.G. (2003). Antecedents of trust in managers: a "bottom up" approach. Personnel Review. 32: 638-64.

Butler, J.K. (1991). Toward understanding and measuring conditions of trust: Evolution of a conditions of trust inventory. Journal of Management. 17:643-63. 
Butt, T. (2008) George Kelly: The Psychology of Personal Constructs. Basingstoke: Palgrave MacMillan.

Cresswell, J.W., Plano Clark, V.L., \& Garrett, A.L. (2008). Methodological issues in conducting mixed methods research designs. In M.M. Bergman (Ed.), Advances in Mixed Methods Research. Thousand Oaks: Sage Publications, pp. 66-83.

Dalton, D.R., Daily, C.M., \& Wimbush, J.C. (1997). Collecting sensitive data in business ethics research: A case for the unmatched count technique. Journal of Business Ethics. 16: 1049-57.

Dunn, J.R. \& Schweitzer, M.E. (2005). Feeling and believing: The influence of emotion on trust. Journal of Personality and Social Psychology. 88: 736-48.

Edmondson, A.C. \& McManus, S.E. (2007). Methodological Fit in Management Field Research. Academy of Management Review 32: 1155-1179.

Feilzer, M.Y. (2010). Doing mixed methods research pragmatically: Implications for the rediscovery of pragmatism as a research paradigm. Journal of Mixed Methods Research. 4: 616.

Fincher, S. \& Tenenberg J. (2005). Guest editorial: Making sense of card sorting data. Expert Systems 22(3): 89-93.

Greene, J. (2007). Mixed Methods in Social Enquiry. San Francisco, CA: Jossey-Bass.

Hammersley, M. (2008). Troubles with Triangulation. In M. Bergmann (Ed.), Advances in Mixed Methods Research. Thousand Oaks, CA: Sage, pp. 22-36.

Jehn, K.A. \& Jonsen, K. (2010). A multimethod approach to the study of sensitive organizational issues. Journal of Mixed Methods Research 4: 313-41. 
Kelly, G.A. (1955). A Theory of Personality: The Psychology of Personal Constructs. New York: W.W. Norton.

Kramer, R. (1999). Trust and Distrust: Emerging Questions, Enduring Questions. Annual Review of Psychology 50: 569-91.

Kvale, S. \& Brinkmann, S. (2009). InterViews: Learning the Craft of Qualitative Research Interviewing. Los Angeles, CA: Sage.

Lee, R.M. (1993). Doing Research on Sensitive Topics. London: Sage.

Lewicki, R.J., McAllister, D.J. \& Bies, R.J. (1998). Trust and distrust: New Relationships and Realities. Academy of Management Review 23: 438-58

Luhmann, N. (1979). Trust and Power, Chichester: Wiley.

Mayer, R.C., Davis, J.H. \& Schoorman, F.D. (1995). An Integrative Model of Organizational Trust, Academy of Management Review 20: 709-34.

McEvily, B. \& Tortoriello, M. (2011). Measuring trust in organizational research: Review and recommendations. Journal of Trust Research. 1: 23-63.

McKnight, D.H. \& Chervany, N.L. (2001). Trust and distrust definitions: One bite at a time. In R. Falcone, M. Singh \& Y.H. Tan (eds). Trust in cyber-societies. Berlin: Springer-Verlag, pp. $27-54$.

Miles, M.B. (1979). Qualitative data as an attractive nuisance: The problem of analysis. Administrative Science Quarterly 24: 590-601.

Molina-Azorin, J.F. (2009). Understanding how mixed methods research is undertaken within a specific research community: The case of business studies. International Journal of Multiple Research Approaches 3: 47-57. 
Molina-Azorin, J.F. (2011). The use and added value of mixed methods in organizational research. Journal of Mixed Methods Research 5: 7-24.

Pidgeon, N. (1996). Grounded theory: theoretical background. In Richardson, J.T.E. (Ed),

Handbook of Qualitative Research Methods for Psychology and the Social Sciences, Leicester: BPS Books, pp. 75-85.

Rousseau, D.M., Sitkin, S.B. Burt, R.S. \& Carmerer, C. (1998). Not so different after all: A cross-discipline view of trust. Academy of Management Review 23, 393-404.

Rugg, G. \& McGeorge, P. (2005). The sorting techniques: a tutorial paper on card sorts: picture sorts and item sorts. Expert Systems 22(3): 94-107.

Saunders, M.N.K. (2011). Trust and strategic change: an organizational justice perspective. In R. Searle \& D. Skinner (eds). Trust and Human Resource Management. Cheltenham: Edward Elgar. 268-86.

Saunders, M.N.K., Altinay, L. \& Riordan, K. (2009). The management of post-merger cultural integration: implications from the hotel industry. Service Industries Journal 29: $1359-75$.

Saunders, M.N.K., Lewis, P. \& Thornhill, A. (2009). Research Methods for Business Students. Harlow: FT-Prentice Hall.

Saunders, M.N.K., Thornhill, A. \& Stead, J. (1997). Downsizing, delayering but where's the commitment? The development of a diagnostic tool to help manage survivors Personnel Review. 26.1/2: 81-98.

Saunders, M.N.K. \& Thornhill, A. (2003). Organisational justice, trust and the management of change: An exploration Personnel Review 32: 360-374 
Saunders, M. N. K. \& Thornhill, A. (2004). Trust and mistrust in organizations: An exploration using an organizational justice framework. European Journal of Work and Organizational Psychology 13: 492-515

Schminke, M. Cropanzano, R. and Rupp, D.E. (2002). 'Organization structure and fairness perceptions: The moderating effects of organizational level' Organizational Behavior and Human Decision Processes, 89, 881-905.

Schoorman, F.D., Mayer, R.C. \& Davis, J.H. (2007). An integrative model of organizational trust: past present and future. Academy of Management Review 32: 344-54.

Sitkin, S.B. \& Roth, N.L. (1993). Explaining the limited effectiveness of legalistic "remedies" for trust/distrust. Organization Science. 4: 367-92.

Tashakkori, A. \& Teddlie, C. (2010). Sage Handbook of Mixed Methods in Social and Behavioural Sciences. ( $2^{\text {nd }}$ edn). Thousand Oaks, CA: Sage.

Teddlie, C. \& Tashakkori, A. (2010). Overview of contemporary issues in mixed methods research. In A. Tashakkori \& C. Teddlie (eds). Sage Handbook of Mixed Methods in Social and Behavioural Sciences. ( $2^{\text {nd }}$ edn). Thousand Oaks, CA: Sage, pp. 1-41.

Van Der Heijden, P.G.M., Van Gils, G., Bouts, J. \& Hox, J.J. (2000). A comparison of randomized response, computer-assisted self-interview, and face-to-face direct questioning: Eliciting sensitive information in the context of welfare and unemployment benefit. Sociological Methods and Research 28: 505-37.

Whaley, A.L. \& Longoria, R.A. (2009). Preparing card sort data for multidimensional scaling Analysis in social psychological research: A methodological approach. The Journal of Social Psychology. 149(2): 105-15.

Willemyns, M. Gallois, C. And Callan, V.J. (2003). Trust me, I'm your boss: trust and power in supervisor-supervisee communication. International Journal of Human Resource Management. 14: 117-27. 
Young, L. \& Daniel, K. (2003). Affectual trust in the workplace. International Journal of Human Resource Management. 14: 139-55. 

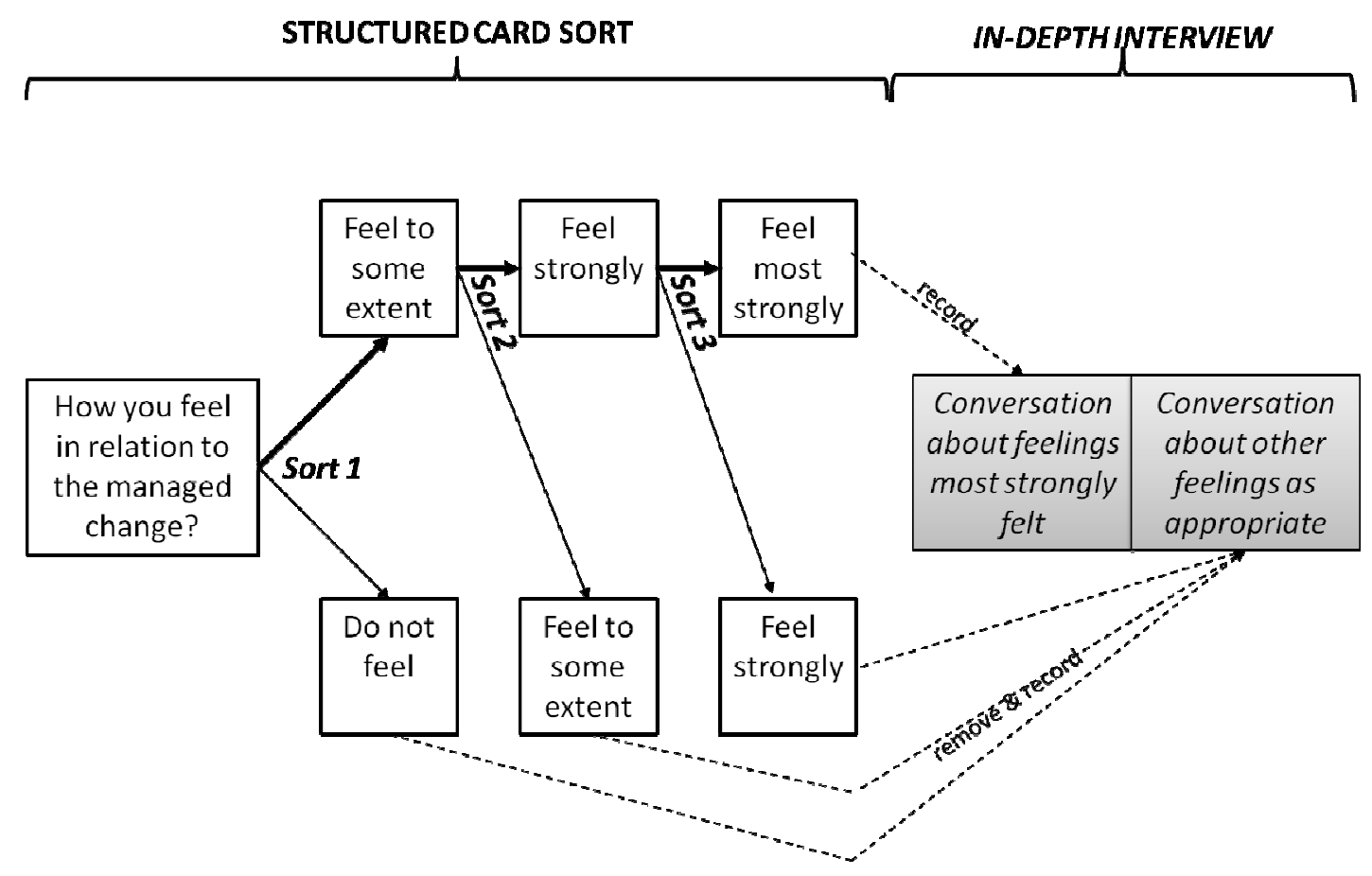

Figure 1: Structured card sort and in-depth interview

Interview number.

Conducted at.

Date.

\begin{tabular}{|ll|c|c|c|c|}
\hline Feeling & Do not feel & $\begin{array}{c}\text { Feel to } \\
\text { some extent }\end{array}$ & $\begin{array}{c}\text { Feel } \\
\text { strongly }\end{array}$ & $\begin{array}{c}\text { Feel most } \\
\text { strongly }\end{array}$ \\
\hline 1 worried & 1 & 2 & 3 & 4 \\
\hline 2 panicky & 1 & 2 & 3 & 4 \\
\hline 3 frustrated & 1 & 2 & 3 & 4 \\
\hline 4 powerless & 1 & 2 & 3 & 4 \\
\hline 5 & depressed & 1 & 2 & 3 & 4 \\
\hline 6 & resentful & 1 & 2 & 3 & 4 \\
\hline & & & &
\end{tabular}

Figure 2: Card sort recording sheet (extract) 


\begin{tabular}{|c|c|c|c|c|c|c|c|c|c|c|c|c|c|c|c|}
\hline \multirow{3}{*}{$\begin{array}{l}\text { Overall } \\
\text { interpretation } \\
\text { of change }\end{array}$} & \multicolumn{12}{|c|}{ Trust/distrust categorisation } & \multicolumn{3}{|c|}{ Total } \\
\hline & \multicolumn{3}{|c|}{$\begin{array}{c}\text { Trusting with } \\
\text { absence of } \\
\text { distrust }\end{array}$} & \multicolumn{3}{|c|}{$\begin{array}{c}\text { Distrustful } \\
\text { with absence } \\
\text { of trust }\end{array}$} & \multicolumn{3}{|c|}{$\begin{array}{l}\text { Neither } \\
\text { trusting nor } \\
\text { distrustful }\end{array}$} & \multicolumn{3}{|c|}{$\begin{array}{l}\text { Both trusting } \\
\text { and } \\
\text { distrustful }\end{array}$} & \multirow[b]{2}{*}{ 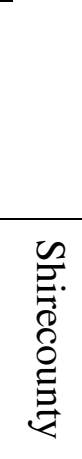 } & \multirow[b]{2}{*}{ 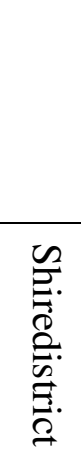 } & \multirow[b]{2}{*}{$\geqq$} \\
\hline & 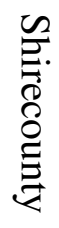 & 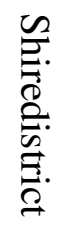 & $\geqq$ & 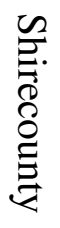 & 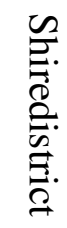 & 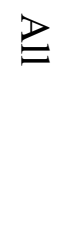 & 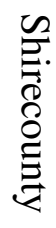 & 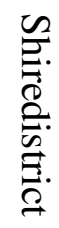 & 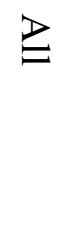 & 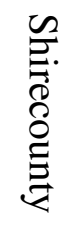 & 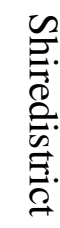 & $\geqq$ & & & \\
\hline Positive & 16 & 6 & 22 & 1 & - & 1 & 2 & 4 & 6 & & & 1 & 20 & 10 & 30 \\
\hline Negative & 1 & - & 1 & 4 & 12 & 16 & 2 & - & 2 & 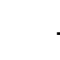 & & 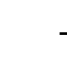 & 7 & 12 & 19 \\
\hline Mixed & 6 & 1 & 7 & - & 5 & 5 & 2 & 1 & 3 & 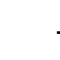 & 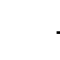 & - & 8 & 7 & 15 \\
\hline Total & 23 & 7 & 30 & 5 & 17 & 22 & 6 & 5 & 11 & c & 1 & 1 & 34 & 30 & 64 \\
\hline
\end{tabular}

Table 1: Participants' feelings of trusting and distrustful and overall interpretation of change 


\begin{tabular}{|c|c|c|c|c|c|c|}
\hline \multirow[b]{2}{*}{$\begin{array}{l}\text { Overall } \\
\text { interpretation } \\
\text { of change }\end{array}$} & \multicolumn{2}{|c|}{$\begin{array}{c}\text { Trusting with absence of } \\
\text { distrust }\end{array}$} & \multicolumn{2}{|c|}{$\begin{array}{c}\text { Distrustful with absence } \\
\text { of trust }\end{array}$} & \multicolumn{2}{|c|}{$\begin{array}{c}\text { Neither trusting nor } \\
\text { distrustful }\end{array}$} \\
\hline & 怘. & 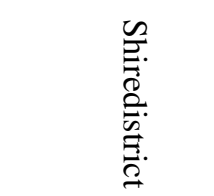 & 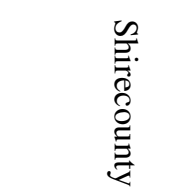 & 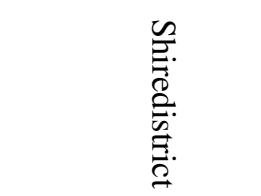 & 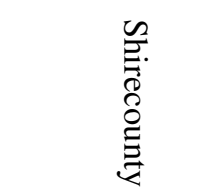 & 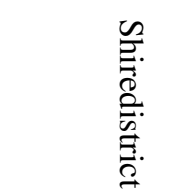 \\
\hline Positive & $\begin{array}{c}\text { positive } 9 \\
\text { involved } 7 \\
\text { determined } 5 \\
\text { enthusiastic } 4 \\
\text { cheerful } 3 \\
\text { optimistic } 3 \\
\text { take initiative } 3 \\
\text { comfortable } 2 \\
\text { confident } 2 \\
\text { keen } 2 \\
\text { under pressure } 2 \\
\text { assured } \\
\text { excited } \\
\text { faithful } \\
\text { hopeful } \\
\text { trusting } \\
\text { vigilant }\end{array}$ & $\begin{array}{l}\text { positive } 5 \\
\text { optimistic } 4 \\
\text { assured } \\
\text { comfortable } \\
\text { confident } \\
\text { determined } \\
\text { enthusiastic } \\
\text { involved } \\
\text { relaxed } \\
\text { take initiative } \\
\text { trusting }\end{array}$ & $\begin{array}{c}\text { enthusiastic } \\
\text { involved } \\
\text { positive }\end{array}$ & & $\begin{array}{l}\text { determined } 2 \\
\text { confident } \\
\text { enthusiastic } \\
\text { optimistic } \\
\text { take initiative }\end{array}$ & $\begin{array}{c}\text { determined } 2 \\
\text { optimistic } 2 \\
\text { positive } 2 \\
\text { calm } \\
\text { comfortable } \\
\text { confident } \\
\text { hopeful } \\
\text { involved } \\
\text { under - } \\
\text {-pressure }\end{array}$ \\
\hline Negative & $\begin{array}{c}\text { angry } \\
\text { frustrated } \\
\text { powerless }\end{array}$ & & $\begin{array}{c}\text { cynical } 2 \\
\text { frustrated } 2 \\
\text { resentful } 2 \\
\text { stressed } 2 \\
\text { demoralised } \\
\text { depressed } \\
\text { resigned } \\
\text { under - } \\
\text {-pressure }\end{array}$ & $\begin{array}{c}\text { concerned } 4 \\
\text { resigned } 4 \\
\text { confused } 3 \\
\text { frustrated } 3 \\
\text { powerless } 3 \\
\text { vulnerable } 3 \\
\text { cynical } 2 \\
\text { demoralised } 2 \\
\text { insecure } 2 \\
\text { under } \\
\text { pressure } 2 \\
\text { wary \& watchful } 2 \\
\text { depressed } \\
\text { determined } \\
\text { panicky } \\
\text { passive } \\
\text { sceptical } \\
\text { worried }\end{array}$ & $\begin{array}{c}\text { stressed } 2 \\
\text { concerned } \\
\text { demoralised } \\
\text { frustrated } \\
\text { under - } \\
\text {-pressure } \\
\end{array}$ & \\
\hline $\begin{array}{l}\text { Mixed } \\
\text { feelings } \\
\text { (both } \\
\text { positive } \\
\text { and } \\
\text { negative) }\end{array}$ & $\begin{array}{c}\text { frustrated } 3 \\
\text { cheerful } 2 \\
\text { determined } 2 \\
\text { sceptical } 2 \\
\text { comfortable } \\
\text { confident } \\
\text { expectant } \\
\text { hopeful } \\
\text { insecure } \\
\text { involved } \\
\text { keen } \\
\text { secure* }\end{array}$ & $\begin{array}{l}\text { concerned } \\
\text { hopeful } \\
\text { optimistic }\end{array}$ & & $\begin{array}{c}\text { concerned } 3 \\
\text { determined } 2 \\
\text { hopeful } 2 \\
\text { under - } \\
\text {-pressure } 2 \\
\text { comfortable } \\
\text { positive } \\
\text { powerless } \\
\text { sceptical } \\
\text { secure } \\
\text { vigilant }\end{array}$ & $\begin{array}{c}\text { confident } \\
\text { frustrated } \\
\text { keen } \\
\text { overwhelmed } \\
\text { under - } \\
\text {-pressure } \\
\text { vulnerable }\end{array}$ & $\begin{array}{l}\text { determined } \\
\text { frustrated } \\
\text { insecure }\end{array}$ \\
\hline
\end{tabular}

*1 Shirecounty respondent only selected 2 feelings about which s/he felt most strongly.

Table 2:Participants selecting each emotion as one about which they felt most strongly 